\title{
AUDIT SISTEM INFORMASI PADA PERUSAHAAN DAGANG ANEKA GEMILANG BANDAR LAMPUNG MENGGUNAKAN FRAMEWORK COBIT 4.1
}

\author{
Putri indah sari \\ 155100093 \\ Universitas Mitra Indonesia, Sistem Informasi \\ putriindahsari.students@umitra.ac.id
}

\begin{abstract}
ABSTRAK
Usaha Dagang Aneka Gemilang merupakan jenis perusahaan dagang yang bergerak dibidang perdagangan, khususnya kebutuhan sarana pembelajaran dari tingkat sekolah dasar sampai perguruan tinggi. Saat ini banyak bermunculan jenis usaha yang sama, hal ini tentunya memperketat persaingan, baik dari sisi kualitas barang sampai kepada kualitas pelayanan terhadap konsumen. Untuk Memastikan kualitas dan layanan yang diberikan oleh Usaha Dagang Aneka Gemilang dapat terarah dan selaras dengan tujuan bisnis perusahaan, perlu diketahui tingkat keselarasan dari tujuan TI dengan tujuan Perusahaan. Untuk dapat mencapai keselarasan antara tujuan TI dan tujuan perusahaan diperlukan suatu pengukuran tingkat keselarasan antara Tujuan perusahaan dengan Tujuan TI menggunakan COBIT 4.1. Dengan keputusan audit ini, diharapkan ada kemajuan yang signifikan terhadap perusahaan. Optimum pelayanan dan memberikan barang berkualitas adalah kegiatan yang harus menjadi prioritas untuk memperkuat mitra bisnis yang tersedia dan mencoba untuk menambahkan mitra bisnis di masa depan, oleh karena Perusahaan Dagang Aneka Gemilang dapat membuka cabang di kabupaten potensial lainnya
\end{abstract}

Kata Kunci: Audit usaha dagang menggunakan framework cobit 4.1 


\section{A. PENDAhULUAN}

Perusahaan Dagang Aneka Gemilang seperti perusahaan-perusahaan dagang lainnya di Indonesia melakukan kegiatan perdagangan dalam skala menengah dan besar, yang jujur, konsisten dan memiliki kualitas dari jenis barang maupun pelayanan terhadap konsumen, sehingga dapat bersaing ditengah-tengah maraknya usaha sejenis yang ada diprovinsi Lampung umumnya dan di Bandar Lampung khususnya. Saat ini ada semacam kecenderungan yang meningkat (growing trend) terhadap dukungan Layanan Pengadaan, dan Pengiriman barang dalam waktu cepat dan tingkat kecocokan barang hampir $100 \%$. Selain itu juga terdapat peningkatan kebutuhan (growing demand) dari pelanggan Perusahaan Dagang, dalam hal ini Kepala Sekolah Direktur, Ketua atau Rektor dari rekanan Perusahaan Dagang Aneka Gemilang, untuk dilayani lebih cepat dan lebih baikLayanan yang diterapkan oleh Manajemen Usaha Dagang Aneka Gemilang terdiri dari 3 proses inti, yaitu Pengadaan (Procurement), Pengiriman (Delivery), dan Pelayanan Optimal (Optimal service). Dilihat dari segi manajemen, ketiga proses tersebut merupakan produk dan jasa inti atau product and services yang ditawarkan usaha dagang kepada pelanggannya. Agar lebih efektif menyelenggarakannya, harus ada aktifitas pendukung yang terkait dengan hal-hal Administrasi, keuangan, sumber daya manusia, infrastuktur perusahaan dan lain sebagainya.
Proses evaluasi kinerja pada Usaha Dagang Aneka Gemilang belum dilakukan, untuk itu diperlukan audit sistem informasi pada Perusahaan aneka Gemilang sehingga masalahmasalah yang ada dapat dikontrol dan diperbaiki, dengan adanya audit dapat di cari sumber masalah yang ada dan dicarikan solusi apa yang akan dilakukan untuk memperbaiki kesalahan sehingga tidak akan terjadi masalah yang sama. Salah satu alat bantu yang digunakan untuk mengetahui permasalahan adalah framework COBIT.Penelitian dilakukan pada layanan pengadaan, pengiriman dan kualitas barang di Perusahaan Aneka Gemilang. Pengukuran audit dilakukan mengacu pada standar framework Cobit pada domain PO8, DS1 dan ME3

- Domain PO8, Mengelola kualitas

- DS10, Mendefinisikan dan

Mengelola tingkat layanan

- Domain ME3, Memastikan Pemenuhan terhadap kebutuhan Eksternal. 


\section{B. TINJAUAN PUSTAKA}

Perencanaan (Planning), melakukan studi literatur terhadap dokumen Perusahaan Dagang Aneka Gemilang yang berkaitan dengan visi dan misi, sasaran tujuan dan rencana strategis Perusahaan Dagang serta menganalisa visi, misi dan tujuan Perusahaan Dagang aneka Gemilang serta strategi, kebijakankebijakan yang terkait dengan pengelolaan investasi IT. Pemeriksaan Lapangan (Fieldwork), Penelitian ini bersifat pendekatan survey. Alat analisis yang digunakan dalam penelitian ini adalah dengan prosedur standar COBIT (Control Objectives for information and related Technology) yang dikeluarkan oleh ISACA (Information systems Audit And Control Association), data yang diperoleh dapat dengan berbagai metode yaitu :

Kuesioner, Yaitu dengan cara membagikan kuesioner kepada setiap bagian yang tergolong Manajemen, Adapun jumlah manajemen yang tersebar sejumlah 10. Selain itu kuesioner yang disebarkan kepada user sejumlah 25 responden sehingga secara keseluruhan didapat total responden 35. Pelaporan (Reporting), Setelah quesioner disebarkan, maka akan didapat data yang akan diproses untuk dihitung berdasarkan perhitungan maturity level. Untuk selanjutnya. dilakukan beberapa tahapan dalam pelaporan yaitu :

- Hasil audit berisi temuan sekarang (current maturity level) dan harapan pada masa yang akan datang (expected maturity level)

- Dilakukan Analysis gap untuk melakukan analisa interpretasi hasil current maturity level dan expected.

- Rekomendasi berisi tindakan korektif mengatasi gap yang dilakukan untuk mencapai perbaikan yang dilakukan untuk institusi tersebut. 


\section{STUDI KASUS}

Secara umum sistem informasi TI saat ini dapat dilihat dari hasil perhitungan tingkat kematangan (maturity level) system informasi Perusahaan Dagang aneka Gemilang pada level Manajemen untuk mengetahui hasil jumlah pendapatannya.

1. Maturity level diperoleh dari hasil rata-rata kuesioner yang disebar kepada responden sejumlah 35 responden yang dibagi menjadi 2 kategori, user dan manajemen.

2. Current Maturity Level dan expectancy user pada Perusahaan Dagang Aneka Gemilang. Secara umum maturity level Perusahaan Dagang Aneka Gemilang dengan menjumlah dan merata-ratakan dari ratarata setiap kategori maka didapat tingkat kematangan. dapat dilihat bahwa rata-rata tingkat kematangan saat ini (current maturity level)

3. domain Deliver and Support berada disekitar level 3 (Defined).Analisa Kesenjangan Manajemen, Ternyata hasil perhitungan current maturity level untuk proses biro manajemen asset dan logistik yang berjalan saat ini berada dibawah.

\section{DISKUSI}

Mengenai studi kasus Perusahaan Dagang Aneka Gemilang seperti perusahaan-perusahaan dagang lainnya di Indonesia melakukan kegiatan perdagangan dalam skala menengah dan besar, yang jujur, konsisten dan memiliki kualitas dari jenis barang maupun pelayanan terhadap konsumen, sehingga dapat bersaing ditengahtengah maraknya usaha sejenis yang ada diprovinsi Lampung umumnya dan di Bandar Lampung khususnya.

\section{E. KESIMPULAN}

Berdasarkan hasil penelitian diperoleh simpulan, proses PO1,DS1,danME3 pada domain Ensure Compliance With External Requirement yang diberikan oleh Perusahaan DagangAneka Gemilang secara umum berada pada tingkat kematangan Defined Process, yaitu terdapat bukti bahwa perusahaan mengetahui adanya permasalahan yang harus diatasi, dan telah diproses menggunakan metode yang telah distandarkan dalam penyelesaiannya, telah mendifinisikan dengan jelas langkah-langkah yang akan dipergunakan dalam menunjang pelayanan. Secara umum pendekatan kepada pengelolaan proses telah terorganisasi secara baik. Gap yang ada baik itu tingkat user maupun manajemen tidak menunjukkan gap yang besar sehingga dapat diambil kesimpulan bahwa apa yang diharapkan oleh Manajemen rata-rata sudah terpenuhi dan system sudah dijalankan.Rekomendasi yang dapat peneliti ajukan adalah tambahkan domain-domain yang dinilai 
sehingga hasilnya akan menjadi lebih baik dari saat ini.Hasil ini diharapkan dapat dijadikan salah satu referensi dalam Sistem Informasi TI secara lebih komprehensif.

\section{F. REFERENSI}

[1] PUTRA, Arie Setya; FEBRIANI, Ochi Marshella. Knowledge Management Online Application in PDAM Lampung Province. In: Prosiding International conference on Information Technology and Business (ICITB). 2018. P. 181-187.

[2] FEBRIANI, Ochi Marshella; PUTRA, Arie Setya. Sistem Informasi Monitoring Inventori Barang Pada Balai Riset Standardisasi Industri Bandar Lampung. Jurnal Informatika, 2014, 13.1: 90-98

[3] Putra, A. S. (2018, July 9). 2018 Artikel Struktur Data , Audit dan Jaringan Komputer. Retrieved from osf.io/3uq8w

[4] Alvin A, Arens, James K. Loebbecke, 2003,

Auditing, Edisi Indonesia, Jakarta, 